\title{
PAMPATHERIUM PAULACOUTOI, UMA NOVA ESPECIE DE TATU GIGANTE DA BAHIA, BRASIL (LEDENTATA, DASYPODIDAE)
}

\author{
CASTOR CARTELLE GUERRA * \\ GERMAN ARTURO BOHORQUEZ MAHECHA **
}

\begin{abstract}
The «Gruta das Onças», a cave situated in the Caatinga do Moura district, municipality of Jacobina, Bahia State, has been a rich source of fossils (Cartelle \& Bohórquez, 1982 and Cartelle, 1983). In this same fossil bed we have found large quantities of skeletal pieces of Eremotherium laurillardi (Lund, 1842), together with Nothrotherium maquinense Lydekker, 1889, Smilodon populator populator Lund, 1842 and a series of skeletul pieces of the giant armadillo which is the object of our present study. In this study we have given special emphasis to the cranium; a comparative study of related species, especially Pampatherium humboldti (Lund), 1839, is made.
\end{abstract}

\section{HISTTóRICO}

Tem sido um pouco confusa a história do gênero Pampatherium Ameghino, 1875 devido, em parte, à dificuldade de comunicação no século passado e a que várias publicações a respeito foram feitas em dinamarquês. Ainda hoje não há unanimidade, entre os diversos autores, especialmente na denominação genérica. A solução do problema foi dada, ao nosso entender, por Couto (1954). Não obstante, alguns erros continuaram a serem mantidos. Resumimos as principais idéias de Paula Couto.

Lund escreveu em Lagoa Santa (Minas Gerais) a sua Segunda Memória sobre a fauna das cavernas, datando-a em 16 de novembro de 1837. Essa Memória só seria, porém, publicada em 1839. Lund propunha, então, para o tatu, «o dobro do tamanho do tatu gigante (Priodontes gigantes Geoffroy de nossos dias», a denominação Clamydotherium humboldti. No mesmo ano, Oersted (1839) antecipou um resumo do

\footnotetext{
* Departamento de Ciências Biológicas da Pontifícia Universidade Católica de Minas Gerais.

** Departamento de Ciências Biológicas da Pontifícia Universidade Católica de Minas Gerais e Instituto de Ciências Biológicas da Universidade Federal de Minas Gerais.
} 
que iria ser publicado mais tarde por Lund, no qual, por lapso, denomina a espécie como Chlamytherium. Segundo o Código de Nomenclatura Zoológica a denominação que deveria prevalecer para o tatu gigante descoberto por Lund é Clamydotherium humboldti Lund, 1839 e não Chlamytherium, pela qual têm optado muitos autores.

Por outra parte, um ano antes, Bronn (1838), descrevendo restos encontrados por Sellow no Brasil e no Uruguai, atribuiu a peças esqueletais de um gliptodonte a denominação de Chlamidotherium. É óbvio por esta razão que, quando foi publicada a Memória de Lund, tal nome estava já pré-ocupado. O nome genérico válido para o «tatu gigante» acabou tornando-se, assim, Pampatherium Ameghino, 1875, sendo Clamydotherium humboldti Lund a espécie tipo.

\section{As Espécies do Gênero Pampatherium}

Não são muito numerosos os restos coletados pertencentes às espécies do gênero. Mesmo com a proposta de Paula Couto (1954) criando a Subfamília Pampatheriinae, na qual se inclui Pampatherium junto com outros gêneros mais antigos, não é uniforme a visão dos autores a respeito dos gêneros do Pleistoceno. Alguns, como James (1957), optam por agrupar as espécies num único gênero; outros, como Hoffstetter (1953), admitem dois gêneros. Castellanos (1957) propõe três. Segundo Hoffstetter teríamos a seguinte situação (levando-se em conta, somente, as espécies pleistocênicas bem estabelecidas):

* Holmesina septentrionalis (Leidy) Simpson, 1930. Do Pleistoceno da América do Norte;

* Holmesina occidentalis Hoffstetter, 1953. Do Pleistoceno do Equador;

* Pampatherium typum Ameghino, 1875. Do Pleistoceno da Argentina, Sul do Brasil, Bolívia e, com dúvidas (Mones-Francis, 1973), no Uruguai.

* Pampatherium humboldti (Lund). Do Pleistoceno de Lagoa Santa, Brasil). Cunha (1978) identificou placas achadas no Rio Grande do Norte como pertencentes a esta espécie (identificação duvidosa, como será discutido adiante). No Ceará e Paraíba também foram assinalados achados (Couto, 1980), assim como na Bahia, como adiante será referido.

Inclinamo-nos pela posição de James (ainda que não aceitemos a denominação genérica), não nos parecendo suficientes as razões aduzidas por diversos autores como Simpson (1930), Hoffstetter (1953) ou Castellanos (1957) para a separação genérica do grupo. As diferenças morfológicas assinaladas não justificam, em nosso entender, a duplicação ou até a triplicação de gêneros. As cinco espécies que propomos para um único gênero (Pampatherium) exemplificam a rica maleabilidade 
destes singulares tatus do Pleistoceno com tão ampla distribuição. No Brasil, foram achados restos esqueletais de três espécies (incluindo a que é descrita neste trabalho). Na Gruta dos Brejões, próxima da que correspondem os achados aqui descritos, encontramos peças esqueletais pertencentes a cinco indivíduos de $P$. humboldti. Os outros achados do Norte do Brasil, diante da descoberta de uma nova espécie, devem ser reexaminados para exata determinação específica. Foram providenciais as descobertas de $P$. humboldti, em região próxima daquela da nova espécie a ser descrita, devido à coleta feita de peças homólogas de ambas as espécies, que forneceram dados preciosos para uma correta comparação. Couto (1980) descreveu um achado de Pampatherium typum em Santa Catarina.

Mantemos o grupo na Subfamília Pampatheriinae, não nos parecendo que deva ser separado em Família aparte de Dasypodidae, como propõem Couto (1980) e James (1957). Ambos aduzem a razão de que os pampatérios são intermediários entre tatus e gliptodontes. Parece-nos que, mesmo peculiares, os pampatérios são verdadeiros tatus. São as seguintes as razões que Couto (1980) indica para considerar o grupo como intermediário:

* os Dasipodídeos, em geral, são insetívoros ou proto-insetívoros; os pampatérios são herbivoros;

* as falanges ungueais posteriores apresentam-se à maneira de cascos ao invés de garras;

* as primeiras vértebras torácicas estão fundidas entre si;

* a carapaça é semelhante à dos tatus, com cintas móveis;

* há aspectos, no crânio, gliptodontóides;

* os dentes posteriores são diferentes dos da maioria dos tatus, por serem bi ou tri-lobados.

Sem dúvida, o conjunto das características fazem dos pampatérios um grupo muito menos afim dos gliptodontes do que dos tatus. A história paleontológica dos pampatérios é conhecida desde o Oligoceno superior, mantendo como que uma linha bem definida e homogênea. Não vemos como não possam ser considerados verdadeiros Dasypodidae especializados, no sentido do gigantismo e da aquisição de hábitos herbivoros; as adaptações subsequentes não os «afastaram» da Família Dasypodidae. Nela encontramos exemplos de formas herbívoras, como na Tribo Eutatini Simpson, 1945. Priodontes giganteus possui falanges distais nos membros posteriores semelhantes a cascos. As variações do número de vértebras e as coossificações não são raras entre os tatus e, especialmente, em formas de maior tamanho. Inclusive há espécies que não apresentam, pelo menos definidas, algo de tão característico como as cintas móveis. Os dentes anteriores têm, nos pampatérios, não 
a forma bi ou tri-lobada mas semi-circular ou oval, característica dos tatus. O crânio, mesmo com algumas remotas semelhanças com o dos glipdontes, não deixa de apresentar uma caracterização típica de tatu.

Parece-nos que os caracteres apresentados como «intermediários»e presentes em diversas espécies da Família não devam ser interpretados como separadores, mas como variação. A Família Dasypodidae surge, assim, com um amplo espectro de formas. Os dentes devem ser interpretados como uma excelente adaptação ao regime herbívoro. A morfologia geral do esqueleto, o focinho truncado obliquamente, os adornos e morfologia das placas, formando cintas móveis ou escudos, entre outras características, tornam os pampatérios verdadeiros tatus. Pelas razões aduzidas, não vemos como os pampatérios possam serem considerados intermediários entre os tatus e gliptodontes. Mesmo especializados, são, acreditamos, verdadeiros tatus.

Sistemática

Ordem EDENDATA Cuvier, 1798

Sub-ordem CINGULATA Illiger, 1811

Super-família DASYPODOIDEA Simpson, 1931

Família DASYPODIDAE Bonaparte, 1838

Sub-família PAMPATHERIINAE Couto, 1954

Pampatherium Ameghino, 1875

$=$ Chlamydotherium Lund, 1839, nec Bronn, 1838

= Chlamytherium Lund, in örsted, 1839

$=$ Glyptodon Leidy, 1839

$=$ Holmesina Simpson, 1930

$=$ Hoffstetteria Castellanos, 1957

\section{Diagnose}

Tamanho avantajado, que ultrapassa o do atual Priodontes giganteus. Carapaça com escudos escapular e pélvico; entre ambos, cintas móveis; tubo caudal não rígido, com anéis; placas grandes com figura central elevada; crânio comprido, com rostro estreito; bula timpânica pouco volumosa; característica expansão pterigoideana; arco zigomático completo, com processo suborbitário; fórmula dentária $9 / 9$ com, pelo menos, o primeiro dente no pré-maxilar; três primeiros dentes não lobulados, sendo os restantes com lobulação e de superficie oclusal plana. Falanges distais anteriores com formato de garras, enquanto as posteriores são encurtadas à maneira de cascos . 
PAMPATHERIUM PAULACOUTOI, sp. nov.

\section{Holótipo:}

Crânio ao qual faltam a porção rostal dos frontais, parte do arco zigomático direito, porção rostro-lateral do maxilar direito, os pré-maxilares e onze molariformes. Úmero direito e esquerdo (02-03); rádios esquerdo completo e direito incompleto (04-05); epífises proximais das ulnas direita e esquerda (06-07); fêmur direito (08); epífises distais da tibia-fíbula esquerda e direita (09-10); calcâneos direito e esquerdo (11-12); astrágalos direito e esquerdo (13-14); navicular direito (15); escápula direita (16); fragmento de coxal (bacia pélvica óssea) com acetábulo esquerdo (917); falanges distais (18-19-23-24-26-28); falanges médias (22-27-31-32); falange proximal dedo III direito (post.). (21); metatarsos II e IV esquerdo (20-25); falange proximal dedo III esquerdo (ant.) (29); unciforme direito (30); vértebras cervicais (33-34); vértebras torácicas e fragmentos (35 a 44); vértebras sacrais incompletas (45); vértebras caudais (46 a 56); apófise transversa de vért. caudal (59); arcos hemais (57-58); costela cervical (60); primeira costela torácica (61); costelas e fragmentos (62 a 85); placas das cintas móveis (86 a 109); placas de outras regióes (110 a 336).

Registrado como MCL-501/01 e, no momento, depositado na Coleção de Palentologia do Museu de Ciências Biológicas da Pontifícia Universidade Católica de Minas Gerais, Belo Horizonte.

Idade Geológica e Localidade

Atribuímos o achado ao Pleistoceno superior ou, mesmo, Holoceno. O material é proveniente da Gruta das Onças, localizada no Distrito de Caatinga do Moura, Municípis de Jacobina, Bahia.

Restos associados: Eremotherium laurillardi (Lund), Nothrotherium maquinense (Lund) Lydekker, 1890, Smilodon populator populator (Lund) e restos ainda não identificados de Milodontidae.

Denominação: a designação específica é dada em homenagem ao Dr. Carlos de Paula Couto, recentemente falecido, a quem tanto devem a Paleontologia brasileira e, particularmente, os autores deste trabalho.

Diagnose

Séries dentárias, a partir do M5 paralelas entre si. Espaços interalveolares muito reduzidos. Diâmetro transverso do forame magno semelhante ao máximo do diâmetro condilar. Bordo caudal da porção horizontal do palatino reto. Presença de marcados seios paranasais. Arco zigomático situado na altura do terço ventral craniano. Côndilos occipitais ultrapassando, ventralmente, o ponto extremo do processo paraoccipital. Placas da carapaça com figuras e adornos bem salientes. 
Será feito o estudo das partes principais do esqueleto, deixando, para outro trabalho, a descrição de diversos ossos carpianos, metacarpianos, falanges, vértebras, costelas; estas peças esqueletais são menos representativas para a determinação específica. No próximo trabalho pretende-se também descrever, conjuntamente, os achados de $P$. humboldti feitos na Gruta dos Brejões (Bahia).

\section{Crânio}

\section{Face Ventral (Fig. 1)}

Os côndilos occipitais têm formato de paralelogramo (com o eixo maior látero-medial) e não quadrangular como em $P$. typum e $P$. humboldti. Nestas duas espécies constata-se que o diâmetro transverso do forame magno (Bordas, 1939 e Winge, 1915) é, aproximadamente, o dobro da largura látero-medial dos côndilos; em $P$. paulacoutoi ambas as medidas são equivalentes. O processo paraocipital estende-se ventralmente até pouco acima da altura alcançada pelos côndilos occipitais, existindo entre ambos os acidentes, uma fenda de cinco milímetros de profundidade. Em $P$. humboldti esta fenda também ocorre, mas o processo é mais ventral do que em $P$. paulacoutoi, sendo tal estrutura menos individualizada em $P$. typum. Profunda fenda separa o processo paraoccipital do processo mastóideo do pétreo. Este, em $P$. humboldti (Winge, 1915) é menos expandido ventralmente do que em $P$. paulacoutoi, no qual chega quase ao mesmo nível do processo paraoccipital. Bordas (1939) confunde esta estrutura, denominando-a «processo pósglenóide». Tal processo, ausente na espécie em descrição, não parece existir, pelo menos bem individualizada, nas espécies descritas do gênero Pampatherium. A este respeito, a espécie argentina é semelhante à de Lagoa Santa.

A borda ventral do forame magno é arredondada, sem apresentar a angulosidade mediana que Winge (1915, Pl. XI, fig. 1) assinala em $P$. humboldti. Interessante peculiaridade apresenta $P$. paulacoutoi na borda ventral; além desta há, internamente, uma crista fina ao longo de todo o percurso, formando-se, pois, uma borda dupla.

Em geral a face ventral do esfeno-occipital apresenta-se nos Dasypodidae plano e quadrangular. Pampatherium, porém, possui tubérculos característicos que forem denominados por Bordas (1939) «tubérculo antero-externo do esfeno-occipital». Na verdade correspondem aos tubérculos musculares destinados à inserção dos músculos retos ventrais da cabeça, que outros mamiferos apresentam. Nessa região, P. paulacoutoi tem duas fossas demarcadas por uma crista mediana e dois tubérculos laterais, que sobressaem, ultrapassando o nível da crista mediana indicada. Esta estrutura em $P$. humboldti tem a linha mediana mais elevada, assim como as citadas fossas e tubérculos mais expandidos rostrocaudalmente.

A abertura nasal caudal é trapezoidal, sendo que a base menor, ventral, corresponde ao bordo caudal da porção horizontal do palatino. Os lados, formados pelos pterigóides, são largos e oblíquos rostralmente. 


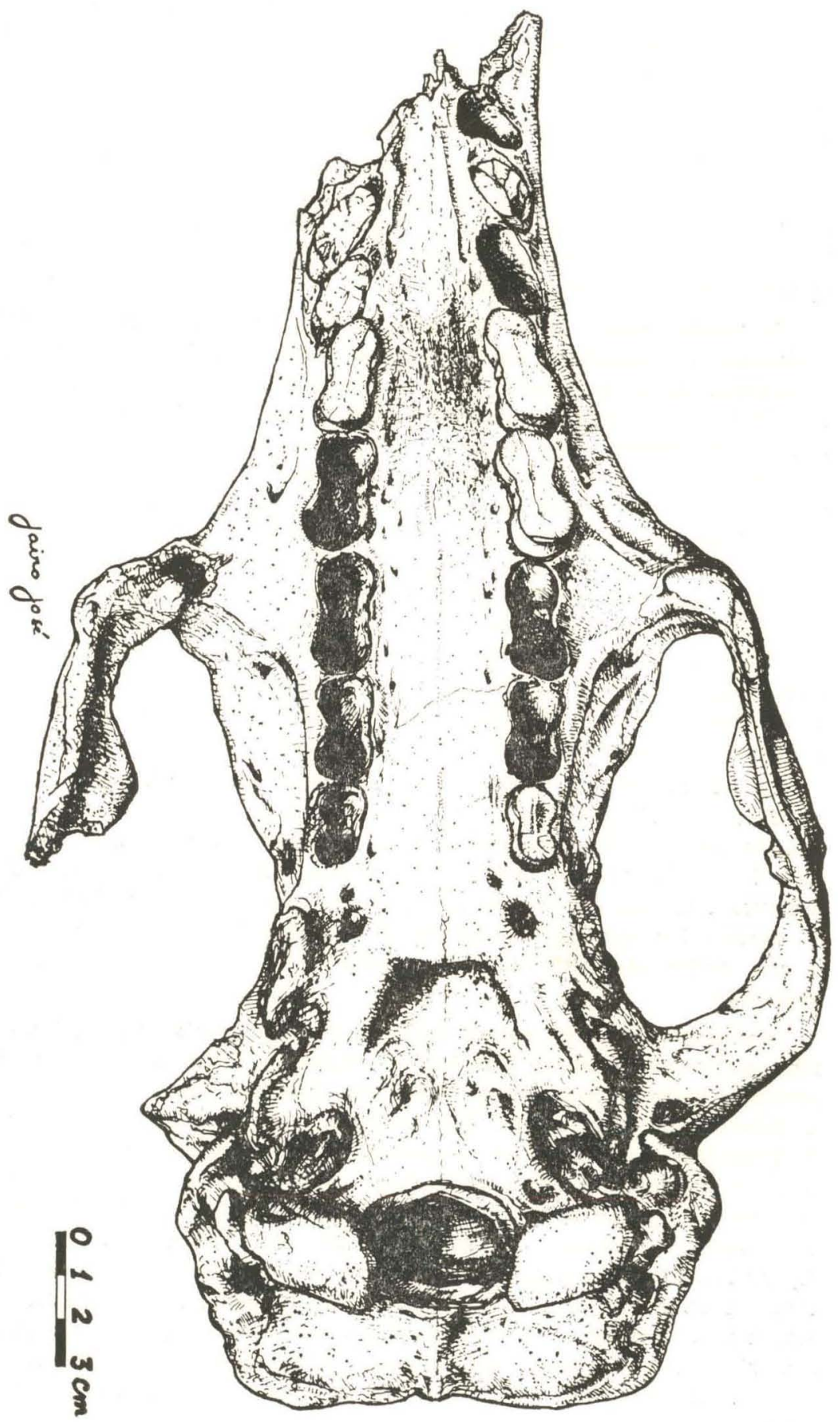

Figura 1 - Pampatherium paulacoutoi, sp.n. Peça MCL 501/01. Crânio, Face ventral. 
Os processos pterigóides têm feição diferente daquela apresentada por outros Dasypodidae; mais do que lâminas, são tubérculos espessos e de superfície rugosa expandidos látero-ventralmente de tal maneira que suas bordas ventrais situam-se a nível mais ventral do que o dos côndilos occipitais e o da face oclusal dos dentes.

Aparentemente, na formulação desses tubérculos, na porção rostroventral, participa o palatino que, acentuadamente, se expande lateralmente. Acreditamos ser esta uma região muito peculiar nos Pampatherinae: $P$. typum, «Holmesina septentetrionalis» e mesmo $P$. humboldti apresentariam semelhante conformação.

O palato mede, desde o bordo caudal, correspondente à porção horizontal do palatino, até o forame incisivo, $202 \mathrm{~mm}$. A porção correspondente ao palatino é plana na região mediana, elevando-se lateralmente para participar na formação dos tubérculos palatino-pterigóides assinalados. Nessa região mediana, à altura do M9, e já correspondendo ao processo palatino do maxilar, inicia-se suave crista palatal sagital contínua até os forames incisivos. A partir da altura citada (M9) o palato torna-se progressivamente mais côncavo, atinge seu máximo ao nível do M5. Nesse percurso, as bordas alveolares linguais apresentam-se paralelas, com uma largura média de $35 \mathrm{~mm}$. Os sulcos palatinos estão perfurados por uma seqüência de forames, dispostos linearmente. A partir da altura do M5 o palato estreita-se lateralmente até formar pronunciado ângulo rostral. Os sulcos laterais acentuam-se neste último percurso. Aparentemente, somente o M1 estaria implantado na pré-maxila. $\mathrm{Na}$ peça não se percebem as suturas palatinas.

A este respeito, a morfologia de $P$. typum, segundo Bordas (1939), se afasta do indicado para a espécie em descrição. Na espécie argentina, a série dentária descreve amplo arco de círculo. Em $P$. humboldti, a série é paralela ao plano mediano até a altura do M4. Em P. septentrionale, a figura oferecida por James (1957) sugere semelhante morfologia à de $P$. typum. No que se conhece de $P$. occidentale (Hoffstetter, 1952), o que restou da série dentária assemelha-se à conformação de $P$. humboldti.

Comparado com as outras espécies afins, $P$. paulacoutoi destaca-se num particular: o espaço interdentário. Todos os dentes situam-se muito próximos entre si, apenas separados pela finíssima lâmina interalveolar, à maneira do que ocorre, por exemplo, em Euphractus sexcinctus. Se tomarmos, para efeito de comparação, a distância compreendida entre as faces caudais dos M3 e M9 e desta subtrairmos o comprimento dos molariformes respectivos, teremos os seguintes espaços interdentários: $P$. occidentale, $14 \mathrm{~mm}$; $P$. humboldti 22,5 mm.; $P$. typum, $22,5 \mathrm{~mm}$. Aparentemente, $P$. septentrionale tem valores aproximados ao que indicamos para $P$. occidentale. $P$. paulacouto $i$ apresenta, a este respeito, a surpreendente medida, correspondente à soma de todos os espaços interdentários, de $7,4 \mathrm{~mm}$ ( $\mathrm{O}$ M4, disposto obliquamente, não foi medido no seu comprimento máximo, mas no espaço compreendido entre M3 e M5). 


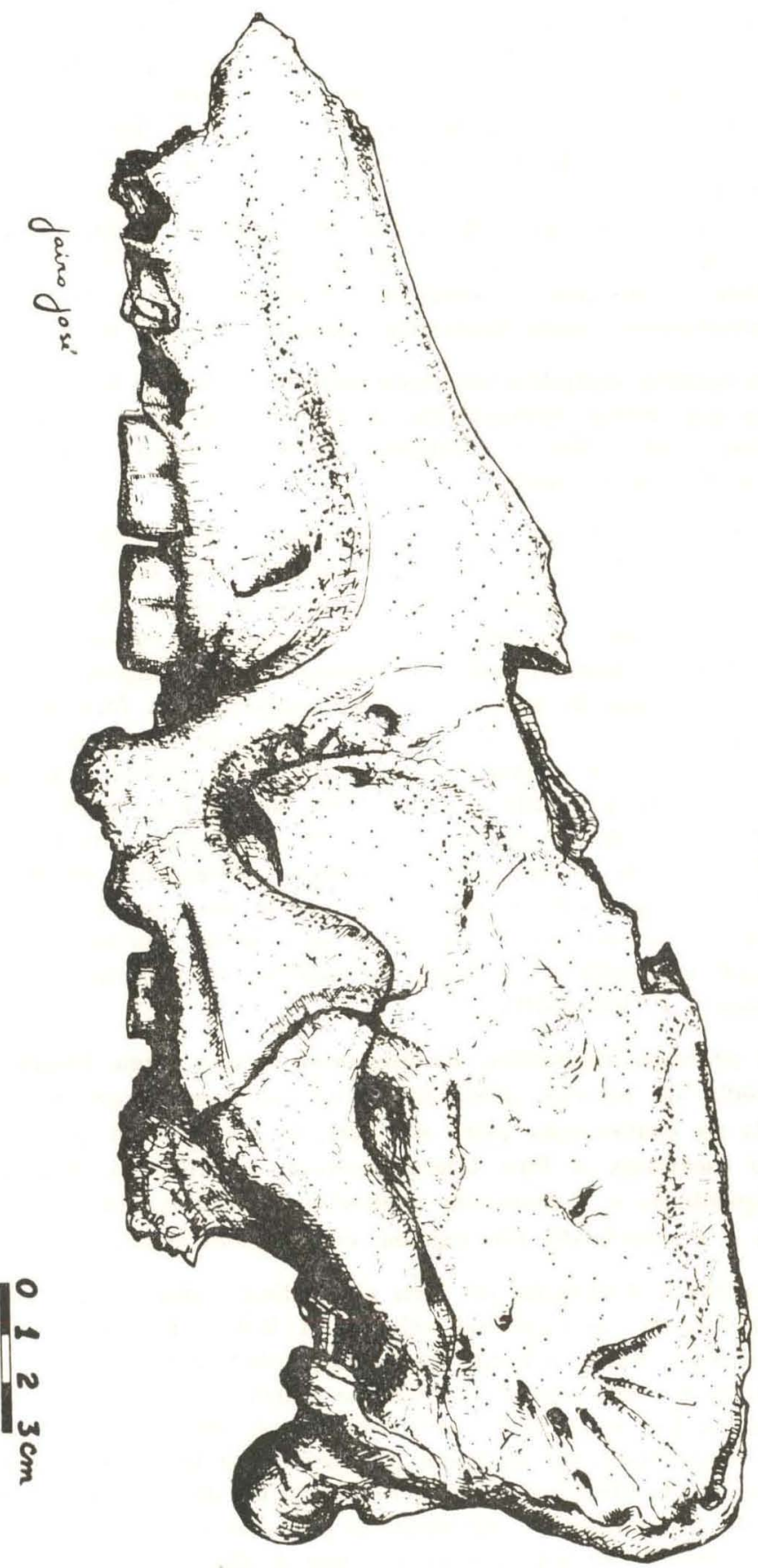

Figura 2 - Pampatherium paulacoutoi, sp.n. Peça MCL 501/01. Crânio. Face lateral 
A conformação geral do crânio é grosseiramente triangular. A interpretação do contorno dorsal fica um pouco prejudicada pela ausência de grande parte dos frontais, como foi indicado. Essa região seria suavemente convexa. Caudalmente, a borda que corresponde à crista nucal é pronunciadamente circular e para trás expandida em aba bem assinalada. A perpendicular ao plano da face oclusal dos dentes, tangente à máxima expansão da crista nucal, passa a um centímetro do extremo caudal do côndilo occipital, como ocorre, aproximadamente, em $P$. typum. Essa feição não se repete em $P$. humbodti: essa linha, assim traçada, cortaria os côndilos à altura do terço caudal. $P$. septentrionale, neste particular, aproxima-se mais de $P$. humboldti.

Os côndilos occipitais situam-se mais ventralmente em P. paulacoutoi do que nos outros pampatérios. A face ventral está ao mesmo nível do plano palatal. Em $P$. humboldti, por exemplo, esta face situa-se ao nivel do forame lacrimal.

O arco zigomático chama a atenção se comparado com o de $P$. typum e, especialmente, com $P$. humboldti. São bem perceptiveis as suturas entre as diversas partes. Inicia-se à altura do M7, quando o malar forma um processo maxilar descendente robusto. O processo zigomático do maxilar não se prolonga, ventralmente, como ocorre, por exemplo, em E. sexcinctus, para participar na formação do arco zigomático. O maior, na continuação, prolonga-se para trás com sinuosa borda ventral. Este ramo horizontal do malar possui a borda dorsal com acentuada expansão no seu terço caudal sem, porém, chegar a atingir a altura do forame lacrimal. E de se notar que, em $P$. humboldti, o malar, quando da formação da apófise descendente, afasta-se mais, em relação ao plano do maxilar, do que em $P$. paulacoutoi. A extremidade ventral do processo maxilar do malar se prolonga, em relação à apófise pterigoideana, mais para baixo, na espécie em descrição, do que em P. typum e $P$. humboldti.

O processo zigomático do escamoso é uma larga lâmina ( $30 \mathrm{~mm}$ em média de altura). Dirigindo-se ao escamoso, descreve um arco, girando na continuação sobre seu eixo, de tal maneira que, na junção com o escamoso, a face lateral torna-se ventral e a medial, dorsal. As rugosidades e a marcante caneladura presentes nos malares de $P$. typum e $P$. humboldti não existem em $P$. paulacoutoi.

Quanto à disposição do arco zigomático, novas e marcantes diferenças surgem no espécime achado na Bahia, se comparado ao de $P$. humboldti. Neste, a borda dorsal do processo zigomático do escamoso é paralela à borda dorsal do crânio e situada à altura do terço dorsal do mesmo. Por essa razão, em vista lateral (Winge 1925), são claramente observáveis, no espécime descoberto por Lund, o alvéolo do M9, o tubérculo do pterigóide e porções (ventrais) do alisfenóide e do escamoso. Já foi indicado o percurso do processo zigomático do escamoso em $P$. paulacoutoi; este percurso ocorre à altura do terço inferior do crânio. Conseqüentemente, colocando-se o crânio em estudo em posição idêntica àquela oferecida por Winge, só é observável o tubérculo 
pterigóide, sendo as outras estruturas que assinalamos como visíveis em $P$. humboldti, ocultas, em $P$. paulacoutoi, sob o arco zigomático; a borda dorsal do processo zigomático do escamoso é, também, oblíqua em relação à borda dorsal do crânio. Conformação semelhante, neste particular, apresenta $P$. typum em relação a $P$. humboldti, sendo o bordo dorsal do processo zigomático do escamoso um pouco mais baixo, em relação ao bordo craniano, na primeira do que na segunda espécie. Em ambas as formas, o processo frontal do malar está mais próximo do processo zigomático do frontal de que em $P$. paulacoutoi. James (1957) poucos elementos fornece para se fazer uma comparação com a espécie norte-americana: aparentemente, a disposição da estrutura em análise, em relação ao todo, assemelha-se ao que assinalamos para P. paulacoutoi.

\section{Face Dorsal (Fig. 3)}

Em P. paulacoutoi o contorno correspondente à crista nucal é suavemente côncavo na sua porção mediana, enquanto $P$. humboldti apresenta, neste local, marcante concavidade, acentuada pela destacada expansão caudal que, lateralmente, a borda occipital manifesta. No espécime em descrição há um suave arredondamento lateral na crista nucal, de morfologia rugosa e largura constante. A fossa temporal é menos acentuada, ao longo da crista sagital, do que em $P$. humboldti, que possui essa região escavada longitudinalmente: situação acentuada pela proeminência da citada crista sagital.

Aparentemente, o perímetro da região correspondente à crista nucal, em $P$. typum, é diferente da descrita para o exemplar da Bahia. Bordas (1939) assim descreve: «cresta occipital blen desarrollada y rugosa en la parte correspondinte al supraoccipital y se hace concava y delgada en la porción que corresponde a los exoocipitales».

Nesta face ressaltam, muito claras, as diferenças entre os crânios descritos por Winge e o que é objeto deste trabalho, no tocante ao arco zigomático e à região temporal. O frontal pouco se expande lateralmente sobre a região orbito-esfenóide em $P$. humboldti. Contrariamente, $P$. paulacoutoi tem marcada expansão nessa área. Por outra parte, o escamoso, no espécime em descrição, é mais expandido lateralmente (em relação ao plano sagital) do que a espécie de Winge. Como resultado, a concavidade retro-zigomática é mais ampla e escavada no espécime da Bahia do que no de Lagoa Santa. As deduções são claras: P. humboldti apresenta o arco zigomático paralelo ao plano sagital craniano e a fossa esfeno-orbital com contorno grosseiramente retangular. Em $P$. paulacoutoi, porém, aumenta progressivamente, em sentido caudal, a abertura do arco zigomático, enquanto que a fossa anteriormente indicada mostra grosseira conformação reniforme.

A destruição dos frontais é compensada pelos acidentes intracranianos que estão à mostra. 


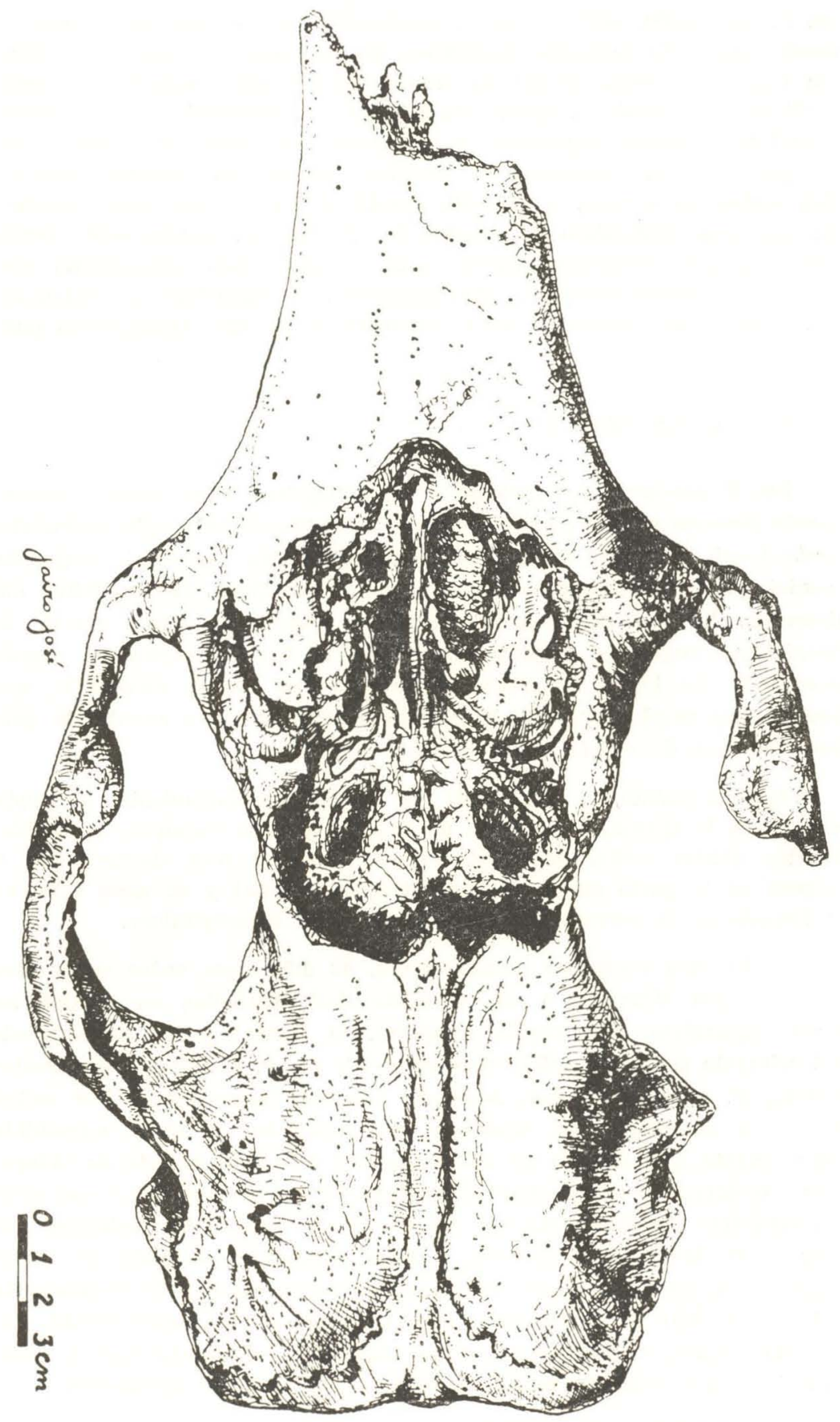

Figura 3 - Pampatherium paulacoutoi, sp.n. Peça MCL 501/01. Crânio. Face dorsal. 


\section{Seios Paranasais}

\section{Seios frontais}

Volumosos e reniformes, localizam-se sob a provável convexidade que os frontais deveriam possuir. Entre eles percebe-se, correspondente ao plano sagital, finíssimo septo. Pelos restos que ainda permanecem na peça, aventamos a possibilidade de ambos os seios não se comunicarem. Ferigolo (1981) assinala essa situação para $E$. sexcinctus. Lâminas ósseas trabeculares finíssimas aumentam a superfície interna ao formarem numerosas câmaras, que são menores medialmente, o que proporciona às paredes do septo um aspecto faveolar. Cada seio possui, aproximadamente, um eixo maior (crânio-caudal) máximo de $55 \mathrm{~mm}$, um eixo menor (látero-medial) máximo de $35 \mathrm{~mm}$ e uma altura máxima (caudal) de $30 \mathrm{~mm}$. O soalho dessa volumosa cavidade correspondente, caudalmente, ao teto rostral da cavidade etmoidal e o terço anterior à região etmoturbinal. Não podemos determinar o limite rostral do seio porque as finas lâminas ósseas obliquas (que teriam essa função), situadas à altura dos processos zigomáticos do frontal (ou pós-orbitários) encontram-se parcialmente destruídas. Nada podemos afirmar, pela mesma razão, a respeito da comunicação deste seio com o que lhe é rostal: o naso-frontal.

\section{Seios Naso-Frontais}

Estes seios têm o osso frontal recobrindo-os na quase totalidade, participando o nasal apenas de pequena porção rostal. A cavidade é ampla. O soalho fino e enrrugado. Este seio recobre, dorsalmente, o meato nasal (dorsal) e, lateralmente, os alvéolos correspondentes aos M6 e M7. Por estar o soalho fragmentado sobre os naso-turbinados não podemos indicar nada a respeito da comunicação entre o meato nasal e este seio. Septos ósseos mais robustos do que no seio frontal localizam-se, especialmente, nas paredes laterais.

\section{Seio Maxilar}

Este pequeno seio se comunica dorsalmente com o anterior através de forame com formato de gomo, de eixo máximo de $15 \mathrm{~mm}$. Situa-se num plano pouco superior ao do forame lacrimal e the é caudal. Na sua formação participam, além do maxilar (que apresenta oco o processo zigomátimo), o lacrimal e pequena porção do frontal (região orbital). Este seio localiza-se, unicamente, na região zigomática do maxilar.

\section{Forames Cranianos}

Preferimos, devido a possuirmos uma peça na qual se percebem nítidos quase todos esses acidentes, descrevê-los em conjunto, ao invés de assinalá-los em cada osso correspondente quando da descrição geral. 
$10 \mathrm{~mm}$ acima da borda alveolar à altura da metade do $\mathbf{M} 6$; o maxilar abre-se à altura da face caudal do M7. O canal, levemente inclinado para cima rostralmente, mede $40 \mathrm{~mm}$ e continua-se caudalmente até a metade do M8, em marcado sulco, além do forame maxilar.

- Forame lacrimal: oval, abre-se sob suave tubérculo, situado a $15 \mathrm{~mm}$ acima da altura máxima atingida pelo malar na formação do arco zigomático. O canal correspondente orienta-se, inicialmente, no sentido dorsal.

- Forame lácrimo-sinusal. Localiza-se na confluência dos ossos maxilar, lacrimal e frontal, sendo menos calibroso do que o forame lacrimal. O canal correspondente orienta-se no sentido dorso-caudal.

- Forame etmoidal. Abre-se sob uma expansão rugosa que, em vista lateral, o encobre. A prolongação da face caudal do M9 tangenciaria anteriormente esse forame, que se situa à altura do lácrimo-sinusal.

- Fenda esfenoidal. De formato oval, orienta-se obliquamente. Não há forames óptico, orbitário e redondo individualizados. Os nervos cranianos II (óptico), $\mathrm{V}_{1}$ (ramo oftálmico do trigêmio), $\mathrm{V}_{2}$ (ramo maxilar do trigêmio), III (óculo motor), IV (troclear) e VI (abducente) tiveram sua passagem nesta fenda.

Fina e conspícua lâmina óssea (dentro da fenda) forma dois claros sulcos dorsais.

Por analogia ao que acontece com outros mamíferos, levantamos a hipótese de que o sulco dorso-medial corresponderia ao forame óptico para o nervo II; o sulco dorso lateral, por sua vez, corresponderia ao forame orbitário para os nervos III, IV, $V_{1}$ e VI; a porção mais ventral da fenda serviria de passagem para $o V_{2}$ e vasos satélites. Esta nossa hipótese é reforçada porque no assoalho desta última porção inicia-se um canal que acompanha o teto alveolar dos últimos molariformes e que consideramos a passagem para os ramos maxilares aveolares caudais (ramo do $\mathrm{V}_{2}$ ).

- Forame esfeno-palatino: arredondado, ventral à fenda esfenoidal e em alinhamento vertical com ela, tem diâmetro de $5 \mathrm{~mm}$, estando situado à altura do forame infra-orbitário. Na cavidade medial desse forame convergem quatro canais, a saber: dorsalmente, destinado à passagem do ramo alveolar caudal do $\mathrm{V}_{2}$; o segundo situa-se rostrolateralmente ao citado. Deste, o terceiro dirige-se, caudalmente, para desembocar no forame palatino maior e que seria destinado a vasos e nervos palatinos; finalmente, o quarto (rostro-medial), que corresponde ao canal esfeno-palatino, seria destinado aos vasos palatinos menores. Tal conformação, parece-nos, nunca foi indicada para os Pampatheriinae.

- Forame oval: arredondado, situa-se lateralmente à mesma altura da fenda esfenoidal, nos limites das porções orbitárias e temporal do alisfenóide. À sua frente insinua-se largo sulco que se dirige até a extremidade ventral da fenda esfenoidal: o percurso do ramo mandibular do nervo $\mathrm{V}$ está bem assinalado até esse local. 
- Forame retroglenóide: de diâmetro e formato semelhantes ao que indicamos para o forame esfeno-palatino, situa-se numa fossa imediatamente após a superfície articular do escamoso para o côndilo mandibular. Tal fossa, ventral, localiza-se na região onde se inicia o processo zigomático do escamoso. Não existe processo retroglenóide.

- Forame estilo-mastóide. Dorsal e anterior à fenda que separa os processos para-occipital e mastóide do pétreo. Lateralmente, desce fino e columelar processo estilóide. O forame (ou fenda) é formado pelo espaço entre os processos estilóide e o mastóide do pétreo.

- Forame supra-mastóide. Arredondado e de proporções semelhantes às do palatino maior. Situa-se na confluência do pétreo, supra-occipital e exoccipital, dois centímetros acima do nível corresponde ao bordo dorsal do forame magno, num sulco obliquo que se continua na profunda fenda que separa os processos paraoccipital e mastóide.

- Devido à falta da bula timpânica, grande fenda continua com formato de letra $\mathrm{C}$, formada pelos bordos laterais do basiesfenóide e basioccipital. E bem marcado o sulco que corresponde à tuba auditiva e que se inicia na porção rostro-lateral dessa fenda, dirigindo-se ao pterigóide, contornando-o medialmente na base da sua porção vertical. Nessa mesma fenda localizavam-se os forames carotídeos, lacerados (médio e posterior), jugular e a fissura petrobasilar. Acreditamos que a forte curvatura caudal formada pelo basi e exoccipital corresponda ao bordo caudo-medial do forame jugular. Concorda a morfologia da fissura «petro-basilar» com a observação de Ferigolo (1981) a respeito da incorreta denominação do acidente: ela é formada pelo pétreo e exoccipital e não pelo basioccipital.

- Forame e canal de hipoglosso. Situado no terço lateral do basioccipital é, aproximadamente, do mesmo calibre do forame esfenopalatino. O canal tem uma direção oblíqua, medialmente, e abre-se no forame condilóide, dorsal à fosseta da face medial do côndilo occipital. Tal fosseta, piriforme, é demarcada ventralmente pelo grosso rebordo ventral do forame magno e, dorsalmente, pela fina lâmina óssea interna que forma como que um segundo rebordo ventral no dito forame.

- Forames palatais:

Fissura Palatina: (rostral) dela somente é perceptível seu pequenc rebordo com formato agudo cujo ângulo coincide, caudalmente, com a linha sagital da porção palatal do maxilar.

Forame palatino maior: Situa-se no começo da expansão látero-ventral do palatino de tal maneira que o plano onde se insere é inclinado. Seu diâmetro é semelhante ao do forame esfeno-palatino, situando-se mais proximalmente do que este. Cinco milímetros adiante, e mais laterais do que os palatinos maiores, localizam-se forames palatinos acessórios, com a metade do diâmetro daqueles. Ao longo da suave inclinação do maxilar, que forma a face mediana dos alvéolos, abrem-se diminutos forames palatinos acessórios.

Os Dentes (Figs. 1 e 4 ) 

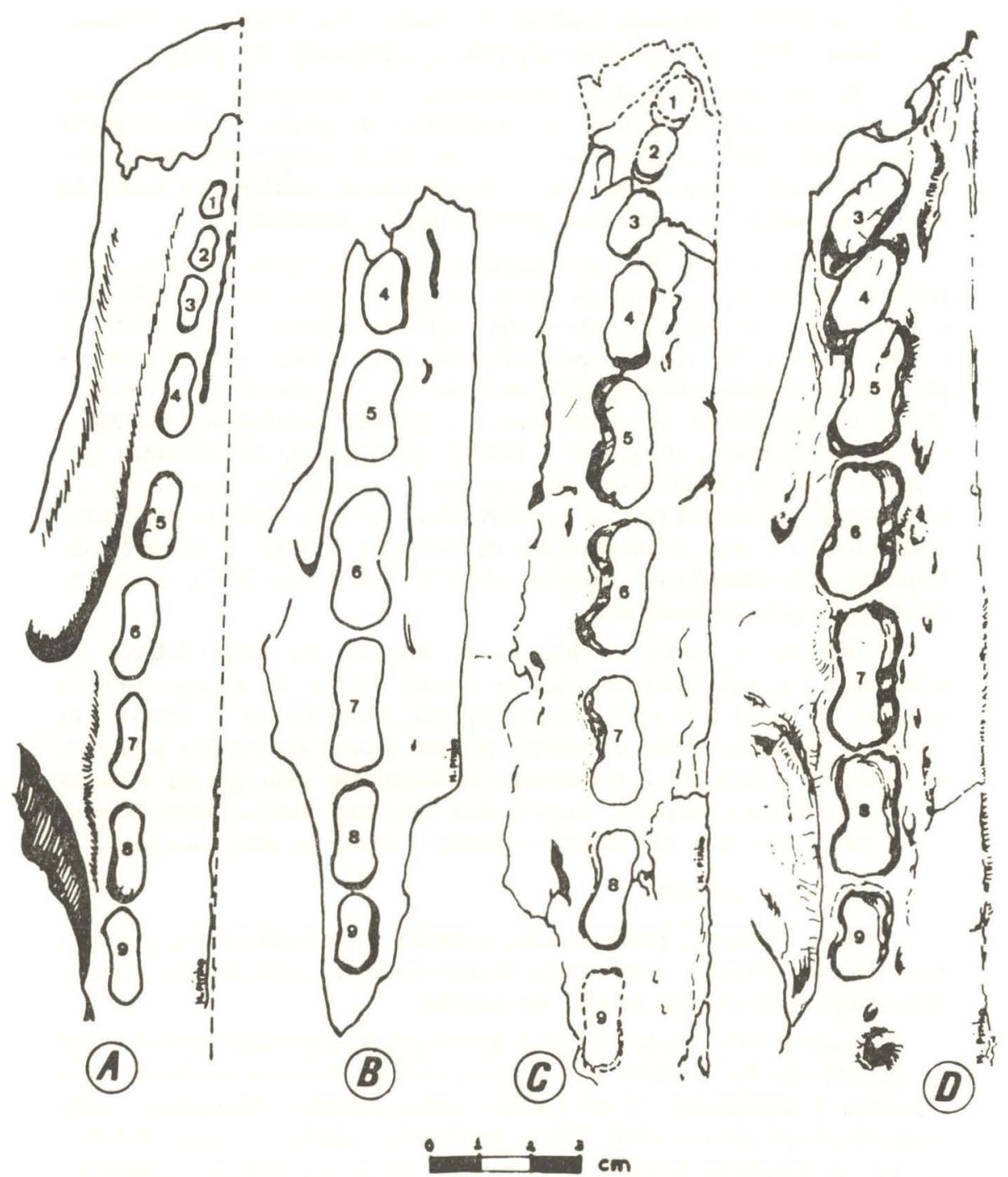

Figura 4 - Séries molariformes superiores direitas. Desenhos na mesma escala. A) Pampatherium typum (In Bordas, 1939). B) Pampatherium occidentale (In Hoffstetter, 1952). C) Pampatherium humboldti (In Winge, 1915). O desenho foi realizado completando-se as partes deficientes com a série esquerda. 
No lado esquerdo encontram-se, nos respectivos alvéolos, os M3, M5, M6 e M9. A metade rostral do alvéolo do M1 encontra-se destruído. No lado direito falta parte do maxilar à altura dos alvéolos correspondentes aos M1, M2, M3 e M4. Os M3 e M4 estão parcialmente destruídos, estando completo, nesta fileira, o M5. Algumas das nossas afirmações serão feitas, pois, através da conformação alveolar.

Podemos inferir que o M1, oval, era, além de fortemente arqueado (a parede alveolar caudal é convexa), inclinado medialmente. Seu maior comprimento, à semelhança de $P$. typum, era no sentido rostro-caudal.

O M2 implantava-se num alvéolo profundo (como, aliás, todos os dentes) e inclinava-se para a frente e para dentro. Seu diâmetro maior era perpendicular ao plano sagital. Em nenhuma das espécies afins, em que se conhece este dente, ocorre tal situação.

O M3 orientava seu eixo maior como em $P$. humboldti, isto é, oblíquo à linha mediana do palato.

O M4 tem perímetro e orientação diferentes do mesmo dente dos outros Pampatheriinae pleistocênicos conhecidos. Quanto à orientação, ela é semelhante à indicada para o M3. Rostralmente é semicircular; lateralmente é reto; caudalmente mostra pequena curvatura que era interrompida pela face posterior do dente, quando alinhado com o M5. $\mathrm{Na}$ face lingual ocorre suave convexidade central do alvéolo, o que permite concluir que a face dentária correspondente era bilobada. Uma tangente imaginária, traçada pelo ponto mais caudal deste dente, cortaria o lobo rostral do M5. Os pampatérios que até aqui têm servido de comparação apresentam este dente com o eixo maior orientado longitudinalmente.

Os M5 e M6 possuem semelhante morfologia: clara bilobulação. Na face vestibular há incisura única e profunda enquanto que na face lingual apresentam três discretos sulcos.

Os M7, M8, e M9 podem ser descritos em conjunto: o comprimento dentário diminui progressivamente da frente para trás, assim como também a bilobulação na face vestibular, sendo, porém, marcante nos três dentes. Na face lingual o M7 implantava-se num alvéolo que possui duas cristas verticais, indicando a existência, no dente, de um terceiro lóbulo intermediário e menor do que os dois outros. Já o M9, na face lingual, possui um único sulco, o que torna esta face, como o vestibular, bilobada. Citando somente algumas diferenças, $P$. typum e $P$. humboldti possuíam trilobulação na face vestibular nos M6, M7 e M8. Através dos trabalhos de Simpson (1930) e Hoffstetter (1952), por exemplo, podem-se constatar outras claras diferenças com as espécies descritas por esses autores.

Aparentemente, pela descrição feita até agora, haveria motivos para $P$. paulacoutoi merecer até uma denominação genérica própria, se comparada com as outras espécies do gênero. Há mais deferenças entre a morfologia craniana da nova espécie e a de qualquer das outras espécies do gênero do que, por exemplo, entre «Holmesina septentrionalis» 
e Pampatherium typum. Acreditamos que, para isso, seja necessário considerar a totalidade da morfologia e não só detalhes morfológicos do crânio, como têm feito alguns autores, ao nosso ver, com exagero e premidos pelo pouco material de que dispunham. Não podemos, porém, esquecer as grandes limitações que apresenta a análise das espécies paleontológicas fundamentadas exclusivamente em variações esqueletais.

No sentido global, as espécies por nós classificadas no mesmo gênero têm uma unidade morfológica bem definida. As adaptações são manifestadas pelas variações morfológicas que, neste caso, definem as espécies. O gênero único indica a unidade do grupo no Pleistoceno. Devemos concluir que as novas condições surgidas desde a transição Plio-Pleistoceno, provocando seja isolamentos geográficos, seja genéticos, tiveram como efeito concreto as variações específicas agrupadas no gênero Pampatherium. O gênero único indica, para nós, a unidade morfológica bem definida no grupo. Parece-nos que os conhecimentos restritos das espécies Pré-pleistocênicas da Subfamília não permitem fazer diferentes afirmações.

Escápula

Na Gruta dos Brejões foi coletada uma escápula direita de $P$. humboldti, à qual somente faltam pequenas porções nas fossas supra e infraespinhais, onde a lâmina óssea é mais fina. Na Gruta das Onças foi recuperada uma escápula, também direita, de $P$. paulacoutoi, fragmentada em pequenos pedaços. Após paciente reconstrução, tornou-se apta para o estudo. Falta, nesta peça, o processo acromial destruído à altura da cavidade glenóide. Nela, a larga e acentuada crista caudal que limita a fossa infraespinhal, forma, em grande parte do seu percurso, a borda caudal da escápula. Em $P$. humboldti, tal crista, menos acentuada e mais estreita, situa-se paralela à borda caudal da escápula, dela separada por uma distância média de dois centímetros. O coracóide é fino e estreito em $P$. paulacoutoi. Contrariamente, tal estrutura, em $P$. humboldti, é larga e robusta. Nesta espécie, a incisura coracoideana descreve um arco de $12 \mathrm{~mm}$ de diâmetro, enquanto que essa medida corresponde a $19 \mathrm{~mm}$ no osso da nova espécie.

\section{Ûmero}

Possuímos, para nosso estudo comparativo, dois úmeros perfeitos de $P$. humboldti, assim como outros dois de $P$. paulacoutoi, um deles (esquerdo) sem a epífise proximal. Destaca-se a maior robustez da peça de $P$. paulacoutoi. Tal peça possui a cabeça articular mais esférica do que a de $P$. humboldti, que é expandida no sentido crânio-caudal. Ainda nesta espécie, não existe o amplo sulco presente na peça da espécie em descrição, entre a cabeça e o tubérculo maior.

Distalmente, na face caudal, situa-se, lateral à faceta articular para a ulna, profunda fossa que demarca a borda lateral da tróclea articular. Tal acidente não ocorre em $P$. humboldti. A face lateral da tuberosidade deltóide é quase plana nesta última espécie; enquanto que, em $P$. paula- 
coutoi, é côncava. Por outra parte, a aba medial da tuberosidade é muito pronunciada na peça de $P$. paulacoutoi, de tal maneira que é formado um marcado sulco na face medial, inexistente em $P$. humboldti.

Na epífise distal, a superfície articular para o ulna-rádio apresenta, também, clara diferença estrutural: o plano correspondente a esse acidente anatômico é paralelo ao plano frontal em $P$. humboldti, enquanto que o mesmo plano na peça de $P$. paulacoutoi forma um ângulo diedro de, aproximadamente, trinta graus com o plano frontal.

Ulna

Na Gruta dos Brejões foi achada uma peça perfeita de P. humboldti, ao passo que, na Gruta das Onças, foram recuperadas duas epífises proximais com as superfícies articulares para o úmero e rádio perfeitas.

A principal diferença, no que podemos comparar entre ambas as peças, reside nas faces medial e lateral nas amplas fossas que as ocupam. A medial é marcadamente mais profunda e expandida, proximalmente, em $P$. paulacouto $i$ do que em $P$. humboldti. Nesta espécie, por sua vez, a fossa lateral, estreita, inicia-se ao nível da metade da distância entre a superfície articular e o extremo proximal do olécrano, enquanto que, na espécie em descrição, a fossa lateral, mais larga, começa ao nível do processo ancônio. A região proximal do osso mostrase, assim, diferente. A crista existente na borda cranial é aguda e marcada no osso de $P$. humboldti sendo, porém, convexa na peça de $P$. paulacoutoi. Na porção mais funda da superfície articular a largura é, também, menor na última espécie citada.

\section{Rádio}

Possuímos, para comparação, uma peça perfeita de $P$. humboldti e duas de $P$. paulacoutoi: uma delas, magnificamente preservada; da outra, só restou sua metade distal. A principal diferença entre as peças de ambas as espécies é que a face interóssea do rádio de $P$. humboldti é suavemente arqueada e longitudinalmente rugosa. Esta disposição faz com que se forme um estreito espaço interósseo ao longo das diáfases radial e ulnar. A morfologia de tal face em $P$. paulacoutoi difere completamente: há profunda faceta articular para a porção ulnar correspondente. O espaço interósseo, antes indicado para a espécie de Minas Gerais, não existe na nova espécie.

Fêmur

Dois fêmures, ambos direitos, são usados para nosso estudo. O pertencente a $P$. humboldti é completo, enquanto que, ao de $P$. paulacoutoi, falta a porção correspondente à cabeça e ao trocânter menor. A cabeça do fêmur foi recuperada, mas não é possível, devido ao tecido ósseo destruído, uma restauração com sua exata orientação.

Não obstante a semelhança, há detalhes morfológicos diferenciadores. O trocânter maior tem sua face proximal com acentuada orientação lateral, em $P$. paulacoutoi, sem expandir, posteriormente, sua extremidade 
próximo-caudal como ocorre na espécie descoberta por Lund, na qual a orientação da superfície proximal do citado trocânter é, sem deixar de ser oblíqua, mais horizontal. O terceiro trocânter, em P. humboldti, tem o bordo proximal semicircular. O mesmo acidente, na espécie em descrição, é menos arredondado e tem a superfície correspondente à inserção tendinosa, menos expandida próximo-distalmente e mais larga crânio-caudalmente. Em conseqüência, a borda lateral se projeta para a frente, mardacamente.

A fosseta supra-patelar é mais rasa e de maior superfície em $P$. humboldit do que em $P$. paulacoutoi. Os côndilos articulares para a tíbia-fíbula apresentam diferente situação nas duas espécies: a maior largura (látero-medial) corresponde, em $P$. humboldti, ao entepicôndilo, enquanto que, em $P$. paulacoutoi, corresponde ao ectoepicôndilo. Outrossim, a orientação do entepicôndilo é paralela ao plano sagital na primeira espécie supracitada, sendo oblíqua na segunda.

Tíbia-Fíbula

De ambas as espécies foram coletadas somente as epífises distais: duas de $P$. paulacoutoi, uma de $P$. humboldti. O volumoso maléolo lateral presente na primeira espécie é muito reduzido no osso de $P$. humboldti. Na superfície articular distal destacam-se as marcas de ampla bolsa sinovial sagital em $P$. paulacoutoi, inexistentes em $P$. humboldti.

As cristas mediais e laterais da face caudal (ou posterior) têm formatos diferentes. A fossa supra-articular é mais côncava em $P$. humboldti do que em $P$. paulacoutoi. A porção tibial que restou no osso desta última espécie tem sua máxima largura no sentido látero-medial enquanto que a máxima largura do osso de $P$. humboldti é no sentido crânio-caudal.

$\mathrm{Na}$ face cranial (ou anterior) há profundo sulco entre o bordo lateral da superfície articular e o maléolo na peça de P. paulacoutoi; tal sulco só é insinuado na peça homóloga da espécie descoberta por Lund.

\section{Calcâneo (Fig. 5)}

Possuímos, para comparação, dois calcâneos de $P$. paulacoutoi e um de $P$. humboldti.

O «tuber calcis» é mais largo e arredondado, dorsalmente, na peça de $P$. paulacoutoi sem se formar, nela, a aguda crista presente em $P$. humboldti. A extremidade distal é mais robusta e de arestas, para a inserção tendinosa, mais salientes na primeira do que na segunda espécie. Nas facetas articulares para o astrágalo falta, na peça correspondente a $P$. paulacoutoi, a depressão que rodeia, distalmente, a faceta ectal da de $P$. humboldti. O «sulco talis» é também diferente: sua metade distal é de tal maneira estreita e rasa que as superfícies ectal e 

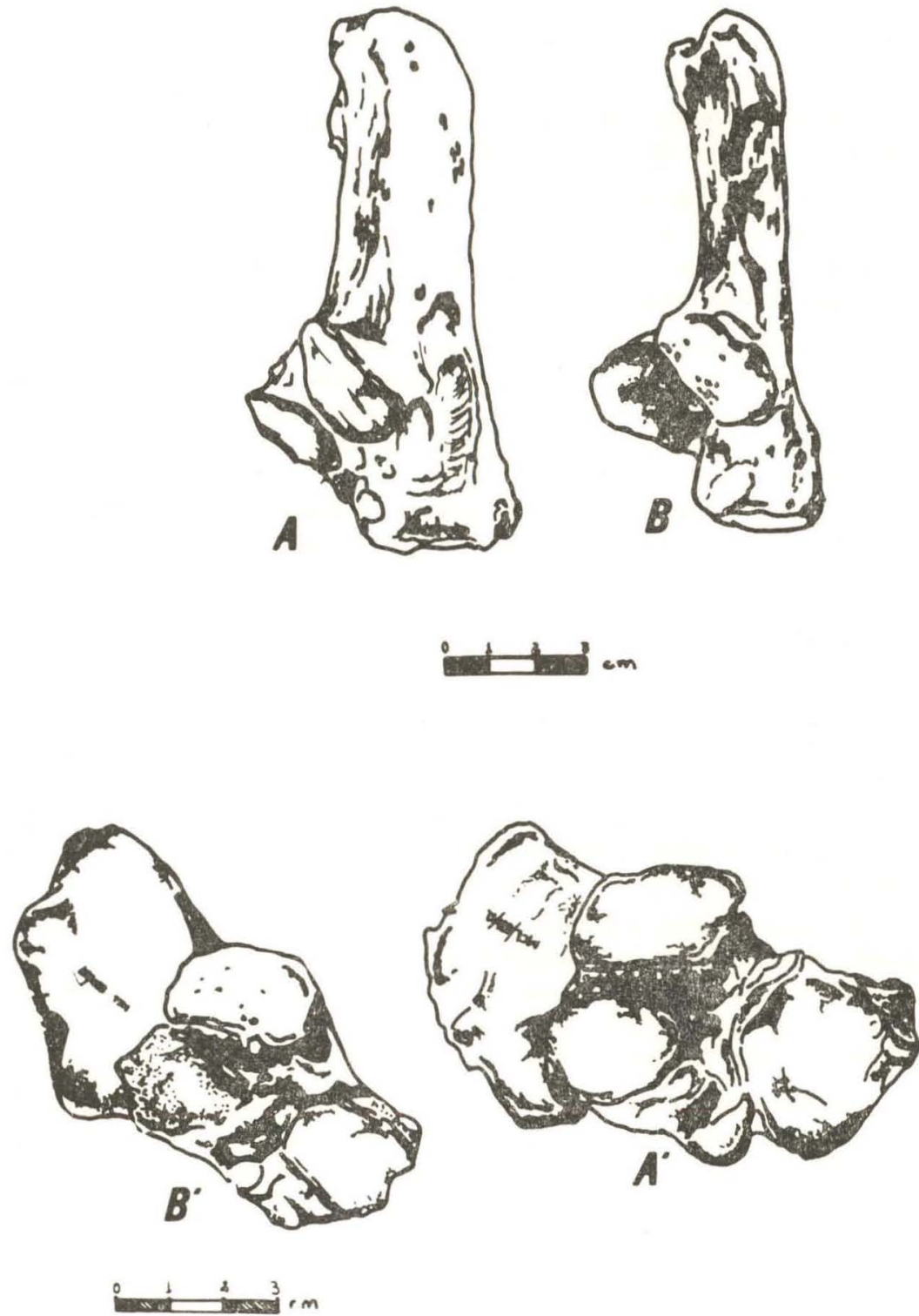
sustentacular quase se tangenciam na peça da espécie descoberta por Lund. Contrariamente, na espécie em descrição, em quase toda a extensão, tal sulco é fundo e marcando a maior separação entre as facetas, distalmente. Enquanto que as facetas situam-se, praticamente, no mesmo plano na peça de $P$. humboldti, a sustentacular está em plano mais dorsal em $P$. paulacoutoi. Nesta espécie, as facetas expandem-se nos sentidos lateral (a ectal) e medial (a sustentacular) mais acentuadamente do que ocorre na espécie descoberta em Lagoa Santa.

Na extremidade proximal da peça pertencente a $P$. paulacoutoi, sob a faceta sustentacular, há volumoso e expandido tubérculo, apenas insinuado na peça de $P$. humboldti.

Pela orientação do eixo maior da faceta articular para o cubóide, concluímos que a posição do tarso em $P$. paulacoutoi é praticamente horizontal ao plano de marcha, enquanto que em $P$. humboldti o tarso é oblíquo medialmente.

Na face plantar da peça correspondente a $P$. humboldti há uma aguda crista longitudinal orientada lateralmente; a crista homóloga da peça da nova espécie é desproporcionalmente larga e rugosa, ocupando praticamente toda a face; na borda proximal dessa face existe uma tuberosidade irregular, como resultado de ser a faceta articular para o cubóide mais aprofundada e o tubérculo, antes indicado na extremidade proximal, ser muito expandido para a frente. Em $P$. humboldti inexiste esse acidente.

Astrágalo

Dispomos de quatro peças de $P$. humboldti, encontradas na Gruta dos Brejões, e de duas de $P$. paulacoutoi da Gruta das Onças. Na face dorsal da peça desta espécie, a faceta articular para a tíbia, com formato de carretel, possui a polia lateral mais convexa e expandida no sentido crânio-caudal do que a correspondente de P. humboldti; a borda (cranial) corresponde à faceta articular para o navicular é mais côncava na nova espécie do que na descrita por Winge.

$\mathrm{Na}$ face cranial, a faceta citada (para o navicular) é, proporcionalmente, mais estreita no sentido dorso-ventral, na espécie em descrição, do que na que nos serve como comparação. Nesta, o plano no qual se situa a faceta articular (sustentacular) para o calcâneo é acentuadamente menos projetado, caudalmente, do que em $P$. paulacoutoi.

$\mathrm{Na}$ face plantar, se comparados os tamanhos relativos e a orientação dos eixos máximos de ambas as peças, percebe-se que na de $P$. paulacoutoi a superfície articular ectal é mais avantajada do que a sustentacular, enquanto que em $P$. humboldti tais facetas articulares têm as superfícies e eixos maiores, aproximadamente equivalentes.

Placas Ósseas (Fig. 6)

Foi coletada grande quantidade de placas de $P$. humboldti, ultrapassando seu número de mil, pertencentes a, pelo menos, quatro indivíduos. Do espécime que temos usado para comparação com o da nova 

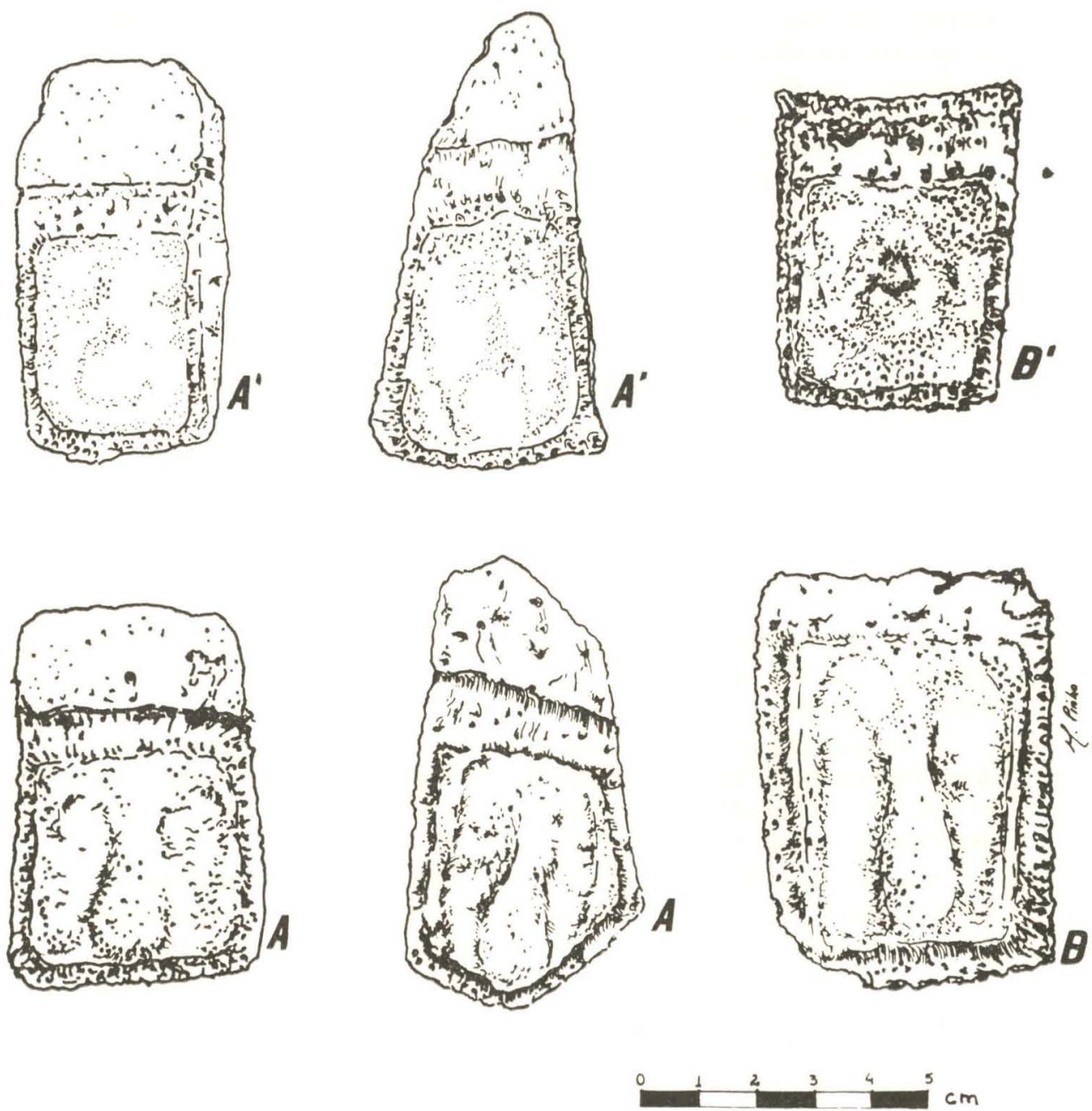
espécie, praticamente, a maioria das que deveu possuir, foram coletadas. De $P$. paulacoutoi possuímos 250 (duzentos e cinqüenta) sendo que 23 (vinte e três) pertencem às cintas móveis. Pela morfologia óssea, os dois espécimes que vimos comparando eram adultos: todas as epífises se acham bem ossificadas com as diáfases. Em geral, as placas de $P$. paulacoutoi são de maior tamanho e espessura do que as de $P$. humboldti; nestas, os orifícios para os pelos parecem ser mais numerosos do que nas placas de $P$. paulacoutoi.

Nas placas pertencentes à espécie descoberta por Lund a seção central é pouco elevada e com numerosos forames que, em geral, diminuem seu diâmetro da periferia para o centro. Nas placas das cinturas móveis insinua-se suave elevação longitudinal central. Nas correspondentes aos escudos fixos essa elevação é comumente oval. Já em $P$. paulacoutoi, os forames têm diâmetro maior e são de distribuição homogênea por toda a superficie dorsal, sem se concentrarem os de menor diâmetro. Todas as suas placas mostram elevação mais acentuada na figura central do que as de $P$. humboldti, chegando a ser muito nítido, pela sua saliência, o bordo poligonal que delimita a figura central. O adorno, em geral, consiste numa saliência posterior longitudinal que, em algumas peças poderíamos até denominar como de verdadeiros tubérculos. A este respeito há uma semelhança maior com $P$. occidentale (Hofstetter, 1952) do que com P. humboldti.

Aventamos a hipótese de que $P$. paulacoutoi tenha possuído menor número de placas formando sua carapaça do que possuiu $P$. humboldti: o tamanho das placas homólogas, sendo os espécimes comparados de idades e tamanhos semelhantes, ao ser mais avantajado em $P$. paulacouto $i$ autorizam esta hipótese.

\section{Agradecimentos}

Ao CNPq (Conselho Nacional de Desenvolvimento Científico e Tecnológico), que nos concedeu o apoio financeiro necessário para as pesquisas de campo.

A nossos alunos José Enemir dos Santos, Edeltrudes Maria Valadares Calaça, Dália Rizel Nogueira, Virgínia Simão Abuhid, Gisele Lessa e João B. Drumond, pela ajuda que nos têm dedicado. Da mesma maneira os colegas Profs. N. Carnevalli e S. Rigueira.

Aos Srs. Manoel Antônio de Carvalho e Paulo Teodoro do Nascimento, funcionários do Depto. de Ciências Biológicas da Pontíficia Universidade Católica de Minas Gerais, pela colaboração que sempre nos prestam.

Ao Prof. Altamirando Marques pelo apoio que sempre tem dado à Equipe de Paleontologia da PUC-MG, quando das escavações na Gruta das Onças.

Ao Reitor da PUC-MG, Prof. Gamaliel Herval, pelo estímulo que nos proporciona ao acreditar no nosso trabalho.

Finalmente aos Srs. Jairo Drummond e Mário Pinho que realizaram os desenhos constantes neste trabalho.

A todos os nossos agradecimentos. 
TABELAS DE MEDIDAS (em $\mathrm{mm}$ )

\begin{tabular}{|c|c|c|c|c|c|c|}
\hline Cranio & 1 & 2 & 3 & 4 & & \\
\hline Comprimento máximo $\ldots \ldots \ldots \ldots \ldots$ & 282 & 315 & 290 & 350 & & \\
\hline $\begin{array}{r}\text { Largura do palato entre os dentes } \\
\text { post. } \ldots \ldots \ldots \ldots \ldots \ldots \ldots \ldots \ldots \ldots \ldots\end{array}$ & 30 & 35 & 40 & 52 & & \\
\hline Largura craniana nas cavidades temp. & 82 & 67 & & 59 & & \\
\hline Diâmetro máximo do forame magno .. & 32 & 32 & 25 & & & \\
\hline occipit. $\ldots \ldots \ldots \ldots \ldots \ldots \ldots \ldots \ldots$ & 90 & 87 & 70 & 70 & & \\
\hline Dentes (compr. rostro-caudais) & 1 & 2 & 3 & 4 & 5 & 6 \\
\hline Comprimento da fileira superior .... & 180 & 197 & 167.5 & 156 & & \\
\hline 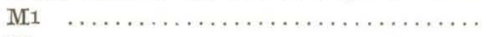 & & 8.3 & 10 & 7.8 & & 9.5 \\
\hline 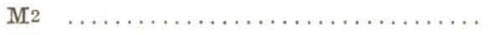 & 12 & 11 & 12 & 8.2 & & \\
\hline 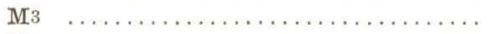 & 19 & 13 & 142 & 9.6 & & \\
\hline 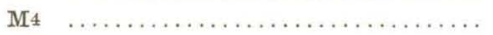 & 20.4 & 19.5 & 17.2 & 15.8 & 16.2 & \\
\hline 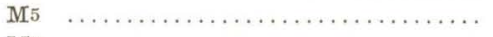 & 26.4 & 24.5 & 212 & 169 & 21.5 & 19 \\
\hline 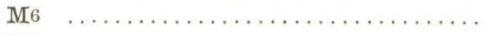 & 26 & 26 & 23.2 & 19.4 & 26 & 21.8 \\
\hline 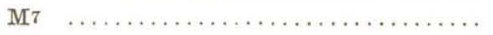 & 26.2 & 24.5 & 23.5 & 17.5 & 25.5 & 20.2 \\
\hline 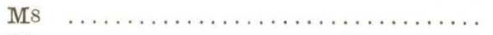 & 22.8 & 22 & 21.2 & 17.4 & 21.4 & \\
\hline 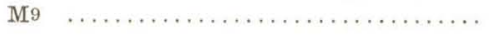 & 15.7 & 18 & 13.2 & 17.9 & 15.5 & \\
\hline Escápula & 1 & 2 & 7 & & & \\
\hline Compr. rostro-caudal da cav. glenóide & 49 & 49 & 47.4 & & & \\
\hline Larg. dorso-ventral da cav. glenóide & 30 & 29.5 & 29,5 & & & \\
\hline Úmero & 1 & 2 & 3 & 7 & & \\
\hline Larg. máxima da epífise prox. .. & 68.8 & 61 & 57 & 65 & & \\
\hline Larg. máxima da epífise dist. .... & 92.6 & 83 & 81 & 83.5 & & \\
\hline Rádio & 1 & 2 & 3 & 7 & & \\
\hline
\end{tabular}

Comprimento máximo ............. $151 \quad 136 \quad 130 \quad 145$

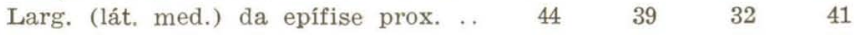

Idem da epifise distal $\ldots \ldots \ldots \ldots \ldots \quad 50 \quad 38 \quad 37 \quad 41$

\begin{tabular}{lllllll}
\hline Fêmur & 1 & 2 & 3 & 7 & 8 \\
\hline
\end{tabular}

Comprimento máximo $\ldots \ldots \ldots \ldots \ldots \ldots . \quad 359 \quad 302 \quad 290 \quad 347 \quad 200$

$\begin{array}{llllllll}\text { Largura transversa no } & 3^{\circ} & \text { trocanter } & 83 & 70 & 72 & 63\end{array}$

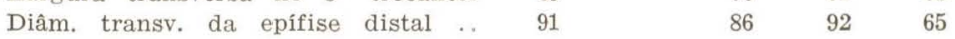

\begin{tabular}{|c|c|c|c|}
\hline Calcaneo & 1 & 2 & 7 \\
\hline Comprimento máximo .............. & 110 & 114 & 104 \\
\hline Largura máxima no tuber calcis .. & 25 & & 18 \\
\hline $\begin{array}{l}\text { Larg. (lát. med.) nas sup. articulares } \\
\text { para o astrágalo } \ldots \ldots \ldots \ldots \ldots \ldots\end{array}$ & 45 & & 41 \\
\hline
\end{tabular}




\section{REFERENCIAS}

BRONN, H. G., 1838. Lethaea geogn. 2: 1258.

BORDAS, A. F., 1939. Craniometría y región auditiva de Clamytherium typum Ameghino. Physis, B. Aires 5(14): 447-459, 3 figs.

CARTElle, C., 1938. Tesouro fóssil no sertão baiano. Ciência Hoje 5: 36-43.

CARTELLE, C. \& G. A. BOHORQUEZ, 1928. Eremotherium aurillardi Lund, 1842. Parte I. Determinação específica e dimorfismo sexual. Iheringia (Geol.) $7: 45-63$, 4 figs.

CASTELlanos, A., 1957. Nuevos géneros de clamitérios y de ciervo y una nueva especie de Phohophorus. Ameghiniana 1(3): 5-14, 4 figs.

COUTO, C. de P., 1954. Sobre um gliptodonte do Uruguai e um tatu fóssil do Brasil. /Dep. nac. Prod. min./ Notas prelim. Estudos 801-10.

COUto, C. de P., 1980. Um tatu gigante do Pleistoceno de Santa Catarina. An. Acad. bras. Cienc. $52(3)$ : 527-531.

CUNHA, F. L. S., 1978. Explorações paleontológicas no Pleistoceno do Rio Grande do Norte, 46 pp., 12 pls. Escola Superior de Agricultura. Mossoró.

FERIGOLO, J., 1981. Osteologia do sincranio e odontologia de Euphactus sexcintus, 311 pp., figs. Dissertação, Curso de Pós-Graduação em Geocincias, UFRGS, Poêrto Alegre.

HOFFSTETTER, R., 1952. Les mammifères pléistocènes de la République de l'Équateur. Mém. Soc. geól. Frr. (n.s.) 21(1-4): 1-391, pls. I-VII.

HOFFSTETTER, R., 1953. Sur la présence d'un tatou géant Holmesina dans le Pléistocène de l'Équateur (Amérique du Sud). C. $r$. Somm. Soc. geól. Fr, 6 .

JAMES, G. T., 1957. An edentate from the Pleistocene of Taxas. J. Paleont. 31: 797-808.

MONES, A. \& J. C. FRANCIS, 1973. Lista de los vertebrados fósiles del Uruguay. II (Mammalia). Com. paleont. Mus. Hist. nat. Montev. 4(1): 39-97.

OERSTED, H. C. 1839. Oversigt over det Kongelike Danske Videnskabernes Selskabs Forhandlinger og dets Medlemmers Arbeiter $i$ Aaret 1838, pp. 5-14. Copenhagen.

SIMPSON, G. G., 1930. Holmesina septentrionalis, extinct giant armadillo of Florida. Am. Mus. Novit. 442: 1-10.

WINGE, H., 1915. Jordfunde og nulevende (Edentata) fra Lagoa Santa, Minas Gerais, Brasilien. E. Mus. Lundii, Copenhagen 5(3): 1-321, 42 pls. 